\title{
Implementing legal accountability to reduce maternal mortality and morbidity in Uganda
}

\author{
Daphine Kabagambe Agaba \\ Post-Doctoral Researcher, School of Public Health, University of the Western \\ Cape, South Africa
}

\begin{abstract}
Summary
Accountability is a vital human rights principle to address preventable maternal morbidity and mortality in Uganda. The continuous use of 'accountability' as a term without elaborating on it gets in the way of using its underlying principles to improve laws and policies. The implementation of legal accountability requires creating avenues through which women whose maternal health rights have been violated may access legal remedies. The existence of adequate legal remedies is vital not only for redressing violations of rights but also for identifying and proposing strategies towards addressing the bottlenecks in health systems. Courts of law are principal judicial mechanisms and, therefore, it is incumbent upon courts to expand rather than limit maternal healthrelated rights. The Uganda Human Rights Commission is another body which is empowered with a protective and promotional mandate that should be used to promote and protect reproductive health rights. It is further emphasised that accountability is not a tool to be understood and interpreted only by legal practitioners. Rather, various forms of accountability, including social and administrative forms, are vital for complementing legal accountability in reducing preventable maternal mortality and morbidity.
\end{abstract}

Key words: accountability; human rights; maternal mortality and morbidity; access to justice

* BSWASA (Kyambogo) MPhil (Pretoria) PhD (Western Cape); agabadaphine@gmail.com. Funding received from the South African Research Chair in Health Systems, Complexity and Social Change supported by the South African Research Chair's Initiative of the Department of Science and Technology and National Research Foundation of South Africa (Grant 82769). Any opinion, finding and conclusion or recommendation expressed in this material is that of the author and the NRF does not accept any liability in this regard. 


\section{Introduction}

Despite various programmatic and legislative strategies, maternal mortality and morbidity rates in Uganda remain unacceptably high and need to be addressed urgently. The most recent official statistics put the rates at 368 per 100000 live births, a reduction from 438 recorded in 2011. ${ }^{1}$ These numbers are still much higher than the Sustainable Development Goal (SDG) target of 70 per 100000 live births that is envisioned by $2030 .^{2}$ These statistics should also be viewed with caution as they often mask deep regional in-equalities, with some areas recording considerably higher ratios than those reported officially. ${ }^{3}$ The direct causes of high maternal mortality and morbidity rates are well known, and include sepsis; unsafe abortions; haemorrhage; obstructed labour; and hypertensive disorders. Unsafe abortions have also been noted to be very common among teenagers, especially those living in rural areas. ${ }^{4}$

Furthermore, pregnancy increases the risk of maternal deaths from HIV/AIDS, hepatitis, anaemia and malaria. While the prevalence rate of HIV stands at 7,3 per cent, it is estimated that 3,1 per cent of HIV/ AIDS deaths are directly related to maternal causes. ${ }^{5}$ HIV affects women in several ways. HIV infection among pregnant women increases the risk of obstetric complications; the incidence of HIV as well as its progression may be aggravated by pregnancy; and illnesses related to HIV, such as tuberculosis and anaemia, might be worsened by pregnancy. The quality of care for women whose HIV-positive status is known may also be lower than the care for those who are not HIV positive. ${ }^{6}$ Other factors include the lack of access to much-needed contraceptives that are vital to reduce exposure to incidences of unplanned, unwanted pregnancies and reduce vulnerability to unsafe abortion, thus contributing to maternal death and morbidity. ${ }^{7}$

The unmet need for family planning is estimated at 34 per cent, while the availability of skilled birth attendants at health facilities is 55 per cent. ${ }^{8}$ Delays, namely, a delay in seeking care; a delay in reaching

1 Uganda Demographic and Health Survey (UDHS) Key Indicators Report, Uganda Bureau of Statistics (2016) 58.

2 World Health Organisation 'SDG3: Ensure healthy lives and promote wellbeing for all ages' http://www.who.int/sdg/targets/en/ (accessed 1 February 2018).

3 UDHS (n 1 above) 58.

4 CEDAW Concluding Observations on the combined 4th, 5th, 6th and 7th Report of Uganda, 47th session, C/UGA/CO/7, 4-22 October 2010 para 35.

5 D Kibira et al 'Availability, prices and affordability of UN Commission's lifesaving medicines for reproductive and maternal health in Uganda' (2017) 10 Journal of Pharmaceutical Policy and Practice 2.

6 C Ronsmans \& WJ Graham 'Maternal mortality: Who, when and why' (2006) 368 Lancet 1194.

7 S Ahmed et al 'Maternal deaths averted by contraceptive use: Results from global analysis of 172 countries' Population, Family and Reproductive Health Department, John Hopkins University of Bloomberg School of Public Health (2012). 
facilities; and a delay to receive much-needed care, also contribute to the high rate of maternal deaths. ${ }^{9}$ Similarly, the measures that need to be taken to reduce maternal mortality and morbidity, including skilled birth attendance; emergency obstetric care; safe abortion services; functional referral systems; and access to good quality and acceptable family planning services, have been set out in maternal health-related plans, policies and programmes. ${ }^{10}$ Yet, maternal mortality and morbidity rates remain unacceptably high.

This article argues that the strengthening of legal accountability mechanisms is vital to address maternal mortality and morbidity in Uganda. It addresses the position upon termination of pregnancy in Uganda and how restrictive and confusing laws contribute to elevate the rate of unsafe abortions. The article explores the available legal avenues in line with maternal health care as well as their shortcomings. It employs the main cases that have been brought before Ugandan courts and how these have been addressed. The article briefly examines the role of the Uganda Human Rights Commission in addressing maternal health care. The role of other forms of accountability in improving legal accountability is also examined, specifically social and administrative accountability.

\section{Termination of pregnancy}

As mentioned above, unsafe abortion is one of the leading causes of maternal mortality and morbidity in Uganda. Thus, the termination of pregnancy merits some special attention before delving into the discussion on legal accountability. Approximately 13 per cent of maternal deaths are attributed to unsafe abortions. ${ }^{11}$ About 1200 women die from unsafe abortion, and 85000 seek treatment for abortion-related complications. ${ }^{12}$ It is estimated that 54 out of 1000 abortions occur under unsafe conditions among women in their reproductive age. As a consequence, 148500 women experience abortion-related complications annually. ${ }^{13}$ The Committee on Economic, Social and Cultural Rights (ESCR Committee) condemned the high rates of unsafe abortions, especially among Ugandan teenagers, and recommended increased access to sexual and

8 Uganda Human Rights Commission 'The 19th Annual Report to the Parliament of the Republic of Uganda' 2016117124.

9 S Thadeus \& D Maine 'Too far to walk: Maternal mortality in context' (1994) 38 Social Science and Medicine 1091-1110.

10 S Lobis 'The role of indicators and benchmarks in reducing maternal mortality: The case of emergency obstetric care indicators' in P Hunt \& T Gray (eds) Maternal mortality, human rights and accountability (2013) 31-37.

11 Republic of Uganda, Ministry of Health 'Reducing morbidity and mortality from unsafe abortion in Uganda: Standards and Guidelines' (2015).

12 As above.

13 AM Moore et al 'Ugandan opinion leaders' knowledge and perceptions on unsafe abortions' (2013) Health Policy and Planning 1. 
reproductive health information and services targeting schools and adolescents. $^{14}$

Uganda's stance on the termination of pregnancy is a restrictive one. Article 22(2) of the Ugandan Constitution provides that no one shall terminate the life of an unborn child except when authorised by law. Furthermore, the Penal Code states that any person or any woman with child who uses any means to procure a miscarriage commits a felony and is liable to imprisonment. It further outlaws the supply of any substance for purposes of procuring a miscarriage. ${ }^{15}$ Conversely, section 224 of the Penal Code provides:

A person is not criminally responsible for performing in good faith and with reasonable care and skill a surgical operation upon any person for his or her benefit, or upon an unborn child for the preservation of the mother's life, if the performance of the operation is reasonable, having regard to the patient's state at the time, and to all the circumstances of the case.

This section can protect a health worker if he or she can prove that the medical abortion was carried out with reasonable care and in good faith to save the life of the mother.

Nevertheless, these Penal Code provisions are restrictive and archaic. The provisions of Uganda's Penal Code Act were imported from the Penal Code of India in 1950, which was an improvement on the eighteenth century British penal law. However, while colonial masters such as Britain have struck out such provisions from their penal laws, they remain firmly entrenched in Uganda's Penal Code. ${ }^{16}$ Ngwena points out the irony in the fact that African countries clamoured for self-rule and autonomy but have maintained restrictive abortion provisions. ${ }^{17}$ Furthermore, the case of Rex $v$ Bourne, ${ }^{18}$ decided in 1938, ruled that the performance of an abortion to preserve both the life and physical and mental health of a pregnant woman was within the realm of lawful abortion. ${ }^{19}$ Subsequently, the British Abortion Act of 1967 took into consideration the grounds established by the $\operatorname{Rex} v$ Bourne decision, but also recognised socioeconomic circumstances as grounds for abortion. However, despite being a British colony and thus adhering to common law system, former British colonies such as Uganda have not revised their laws to reflect such developments in the laws they inherited. ${ }^{20}$ Additionally, activists assert that such ambiguous and archaic provisions create

14 ESCR Committee 'Concluding Observations to Uganda' E/C.12/UGA/CO/1, 8 July 2015.

15 Secs 141-143 of the Penal Code Act 1950, Cap 120.

16 S Tamale 'Exploring the contours of African sexuality: Religion, law and power' (2014) 14 African Human Rights Law Journal 163.

17 C Ngwena 'An appraisal of abortion laws in Southern Africa from a reproductive health rights perspective' (2004) 32 Journal of Law, Medicine and Ethics 708-717.

18 (1939) 1 KB 687 or 3 All ER 615 (1938).

19 Rex v Bourne 1 King's Bench 687, 3 All ER 615 (Central Criminal Court, London 1938).

20 Ngwena (n 17 above). 
room for confusion and uncertainty, and may discourage many health workers from conducting medical abortions for fear of being imprisoned. ${ }^{21}$

Upon ratification of the Protocol to the African Charter on Human and Peoples' Rights on the Rights of Women in Africa (African Women's Protocol), Uganda entered reservations to article 14(1)(a) which calls upon states to respect and protect women's rights to control their fertility, and article (2)(c) of the Protocol, on medical abortion mentioned above. ${ }^{22}$ Uganda interpreted article $14(1)(a)$ to mean that women have the right to control their fertility regardless of their marital status, while article 14(2)(c) was interpreted as conferring an individual right to abortion, thus requiring the state party to provide access to the procedure. Thus, Uganda maintained that it was not bound by this article unless it complied with domestic legislation pertaining to abortion. ${ }^{23}$ Despite recommendations requesting Uganda to withdraw this reservation and to revise its legislation on termination of pregnancy, to date Uganda has not withdrawn its reservation to the Protocol. ${ }^{24} \mathrm{Ngwena}$ argues that the reservations to the African Women's Protocol do not restrict abortion beyond the grounds already laid out in domestic law, including the Penal Code. Furthermore, the reservations to article 14 do not preclude the application of other provisions in the Protocol as well as other treaties that Uganda has ratified without reservations which address themselves to issues of safe abortion. ${ }^{25}$

Despite the vagueness of and confusion about the legal position, in some instances abortion laws are actively enforced, leaving women, girls and health workers vulnerable to law enforcement, with some facing arrest, imprisonment and prosecution. According to a report released by the Human Rights Awareness and Promotion Forum in 2016, at least 182 arrests were made on abortion-related charges

21 Guttmacher Institute 'Abortion in Uganda, Fact sheet' January 2013, https:// www.guttmacher.org/fact-sheet/abortion-uganda (accessed 1 February 2018).

22 Statement by Ms Hannah Forster, Executive Director, African Centre for Democracy and Human Rights Studies and Chairperson of the NGO Forum Steering Committee, at the official opening of the 50th ordinary session of the African Commission on Human and Peoples' Rights, The Gambia, 24 October 2011.

23 JL Asuagbor 'Status of implementation of the Protocol to the African Charter on Human and Peoples' Rights on the Rights of Women in Africa', Commissioner, Special Rapporteur on the Rights of Women in Africa, African Commission on Human and Peoples' Rights 60th Meeting-Commission on the Status of Women 18 March 2016 para 5.

24 Report of the joint promotion mission undertaken to the Republic of Uganda 25-30 August 2013, presented at the 55th ordinary session of the African Commission on Human and Peoples' Rights, held from 28 April to 12 May 2014 in Luanda, Angola 60.

25 C Ngwena 'Taking women's rights seriously: Using human rights to require state implementation of domestic abortion laws in African countries with reference to Uganda' (2016) 60 Journal of African Law 129-131. 
from 2011 to $2014 .^{26}$ The categories of people arrested included women and girls who had undergone abortions; health workers who had performed the abortions; and men who were involved in procuring the abortion. Of the reported cases, very few are prosecuted due to the difficulty in investigating abortion cases as well as the fact that complainants lose interest or are paid off. ${ }^{27}$

Durojaye and Ngwena emphasise that the human right to reproductive health is meaningless if women faced with unwanted pregnancies are forced to either become mothers or to resort to unsafe abortions. ${ }^{28}$ It is also important to note that restricting abortion does not reduce or stop it, but rather drives it underground, thus elevating maternal mortality and morbidity rates as a result of unsafe abortion. ${ }^{29}$ It is for reasons such as these that the abortion figures are staggering. In 2015 the Standards and Guidelines on Reducing Maternal Morbidity and Mortality from Unsafe Abortions in Uganda were issued by the Ministry, aimed at ensuring access to contraceptives, in this way preventing unsafe abortion. ${ }^{30}$ The Guidelines were also aimed at laying down provisions for the safe termination of pregnancy and post-abortion care. However, their dissemination was put on hold as the Ministry of Health felt that it was necessary to consult with various stakeholders, especially religious leaders. $^{31}$

Therefore, the law should be revised and clarified so as to directly respond to and address unsafe abortions as a cause of maternal mortality and morbidity in Uganda. Understandably, in 2017 a petition was brought before the Constitutional Court challenging the failure of the state of Uganda to make a law regulating the termination of pregnancy. The petitioners alleged that the existing law did not protect young girls and women who found themselves with unwanted pregnancies, thus prompting them to resort to unsafe abortions. The petitioners demanded the interpretation of article 22(2) on termination of pregnancy as well as the creation of a framework which would enable Parliament to discuss, formulate and enact a law on termination of pregnancy. ${ }^{32}$ The petition is yet to be addressed. Finally, when seeking to reform abortion laws, the focus

26 Human Rights Awareness and Promotion Forum 'The enforcement of criminal abortion laws in Uganda and its impact on the human rights of women and health workers' Final Version, December 2016, IX-XI.

27 As above.

28 C Ngwena \& E Durojaye (eds) Strengthening the protection of sexual and reproductive health and rights in the African region through human rights (2014) 5.

29 C Zampus \& J Todd-Gher 'Abortion and the European Convention on Human Rights: A lens for abortion and advocacy in Africa' in Ngwena \& Durojaye ( $\mathrm{n} 28$ above) 80 .

30 Human Rights Awareness and Promotion Forum (n 26 above) 16.

31 As above.

32 Centre for Health, Human Rights and Development (CEHURD) Prof Ben $K$ Twinomugisha \& Dr Rose Nakayi v Attorney-General of Uganda Constitutional Petition 10 of 2017. 
should go beyond merely reforming the law to their implementation. Otherwise, legalising abortion without putting in place an elaborate implementation framework, especially for women who are socioeconomically challenged or who lack adequate knowledge and autonomy, often proves to be mere tokenism. ${ }^{33}$ Therefore, beyond adopting laws, steps should be taken to train health care professionals in the provision of accessible services; to allocate sufficient resources based on availability; to de-stigmatise and eliminate discrimination around abortion-related services; and to provide community education on safe abortion and the availability of safe abortion services. $^{34}$

\section{Legal accountability}

Accountability is a word that is commonly used even though its use often does not translate into elaboration or implementation. As put by Boven, the term 'accountability' always is reserved for the titles of governance texts and often is not even mentioned in the texts. He compares it to a 'garbage can filled with good intentions' as it is often not used for purposes of analysis but rather for vague aspirations of governance. ${ }^{35}$ Accountability has three vital elements, namely, responsibility, answerability and enforcement. ${ }^{36}$ Schedler asserts that accountability is the requirement that power should be exercised in a transparent manner as well as demanding that those in power justify their acts; ${ }^{37}$ that answerability involves the right to receive all necessary information and the duty of those in power to justify their actions. Furthermore, enforcement is an integral aspect of accountability as it emphasises that improper behaviour should not go unpunished, otherwise accountability would be viewed merely as window dressing and not as a real restraint on power. ${ }^{38}$ In defining accountability, Joshi and Houtzager emphasise that some form of agreement has emerged about the vital elements that make up the accountability relationship, namely, the set of standards upon which performance is measured; information and justification for actions taken; and sanctioning or recognising behaviour where appropriate. ${ }^{39}$

33 Ngwena (n 25 above) 113.

\section{Ngwena 131.}

35 M Bovens 'Public accountability: A framework for the analysis and assessment of accountability arrangements in the public domain' unpublished paper, Utrecht School of Governance, Utrecht University, The Netherlands, 20054.

36 Office of the United Nations High Commissioner for Human Rights 'Who will be accountable: Human rights and the post-2015 development agenda' New York and Geneva 2013.

37 A Schedler et al (eds) The self-restraining state: Power and accountability in new democracies (1999).

38 Schedler et al (n 37 above) 14-17.

39 A Joshi \& PP Houtzager 'Widgets or watchdogs? Conceptual explorations in social accountability' (2012) 14 Public Management Review 151. 
Hunt explains that accountability allows individuals and communities to understand how those with responsibilities have implemented their duties, enables those with power to explain and justify the actions they have taken and, where shortcomings have been identified, accountability calls for them to be redressed. ${ }^{40}$ Yamin cautions that accountability goes beyond merely apportioning blame and punishing those responsible to developing a dynamic system comprising shared roles and responsibilities between rights holders and duty bearers, where shortcomings can from time to time be reviewed and remedied. ${ }^{41}$

Accountability necessitates numerous forms of oversight and review, including administrative, social, political, international and national legal accountability. ${ }^{42}$ National legal accountability is a vital form of accountability. The ability of people to seek remedies to correct violations is the benchmark of accountability. The realisation of legal accountability requires that public authorities and institutions put in place adequate remedial and corrective measures for those whose rights have been violated. In the case of LC $v$ Peru, the Committee on the Elimination of Discrimination against Women (CEDAW Committee) noted that even though the CEDAW does not expressly mention the 'right to a remedy', it is implicit in articles 12 and 2(c) which provide that state parties should put in place procedures aimed at the protection of women's rights on an equal basis with those of men. These should include legal avenues, national tribunals as well as public institutions aimed at protecting women against any form of discrimination. Furthermore, article 2(f) calls upon the state to take all necessary measures, including legislation, to modify and abolish existing laws, customs, practices and regulations that are discriminatory towards women. ${ }^{43}$ Similarly, in the case of Alyne $v$ Brazil, the Committee pointed out that the state had failed to provide adequate judicial remedies and protection by not initiating proceedings to hold responsible those who had failed to provide timely and adequate medical care for Ms Alyne da Silva. The Committee emphasised that adequate sanctions must be imposed on health professionals who violate women's reproductive health rights. ${ }^{44}$

40 P Hunt \& G Backman 'Health systems and the right to the highest attainable standard of health' (2008) 10 Health and Human Rights 80 at 89.

$41 \mathrm{AE}$ Yamin 'Towards transformative accountability: Applying a rights-based approach' (2010) 7 International Journal of Human Rights 97.

42 United Nations General Assembly 'Technical guidance on the application of a human rights-based approach to the implementation of policies and programmes to reduce preventable maternal morbidity and mortality' Human Rights Council, 20th session, A/HRC/21/22, 2 July 2012 paras 74-75.

43 CEDAW Committee LC $v$ Peru, C/50/22/2009, 4 November 2011 para 8.16-9.

44 CEDAW Committee Alyne da Silva Pimentel Teixeira v Brazil C/49/D/17/2008, 10 August 2011 paras $7(8) \& 8(2)$. 


\subsection{Adjudication of maternal health cases in Ugandan courts}

The judicial sector has a pivotal role to play in upholding accountability. Article 137(1) of the Constitution provides that '[a]ny question as to the interpretation of this Constitution shall be determined by the Court of Appeal sitting as the Constitutional Court'. Article 137(3) states that any person who claims that an Act of Parliament or any other law or anything done by a person or authority is not in line with the constitutional provisions may petition the Constitutional Court for a declaration to the effect or for redress. Article 137(4) states that, if after the determination of the petition under clause (3), the Constitutional Court considers that there is a need for redress, the Court may grant an order for redress or refer the matter to the High Court to determine the suitable redress. The Constitutional Court's jurisdiction in line with article 137 as well as article 50, which is discussed in greater detail below, has been the subject of several cases. In Attorney General $v$ Major General David Tinyefuza, ${ }^{45}$ Justice Kanyeihamba stated:

In my opinion there is a difference between applying and enforcing the provisions of the Constitution and interpreting it. Whereas any court of law and tribunals with competent jurisdiction may be moved by litigants in ordinary suits, applications or motions to hear complaints and determine the rights and freedoms enshrined in the Constitution and other laws under article 137, only the Court of Appeal sitting as the Constitutional Court may be petitioned to interpret the Constitution with a right to appeal to this Court as the appellate court of last resort ... the concurrent original jurisdiction of the Constitutional Court can only arise and be exercised if the petition also raises questions as to the interpretation of the Constitution as the primary objective or objectives of the petition. To hold otherwise might lead to injustice and some situations manifest absurdity.

In Ismail Serugo $v$ Kampala City Council, ${ }^{46}$ the Court held that the Constitutional Court should normally be involved only in matters requiring the interpretation of the Constitution under article 137 of the Constitution. The same position was taken in Dr James Rwanyarare \& Others $v$ Attorney-General, ${ }^{47}$ where the Court noted:

In our view petitions for enforcement of rights and freedoms under article 50 do not belong to this Court ... It seems clear that this court will deal with matters falling under article 50 only by way of reference made to it under article 137(6) which states that '[w] here any question is referred to the Constitutional Court under article 137(5) the Constitutional Court shall give its decision on the question and the Court in question shall dispose of the case in accordance with that decision ...' This court has no jurisdiction in matters not covered under article 137 of the Constitution.

The CEHURD case $^{48}$ was brought in terms of article 137 of the Constitution. The case concerned the death of two women from

45 Supreme Court Constitutional Appeal 1 of 1997.

46 Constitutional Appeal 2/98 SC (1998).

47 Constitutional Petition 7 of 2002 [2004] UGCC 5 (16 November 2004).

48 Centre for Human Rights and Development (CEHURD) \& Others $v$ Attorney-General UGCC Constitutional Petition 16 of 2011, decided 5 June 2012. 
maternity-related causes in two different hospitals. ${ }^{49}$ CEHURD alleged that the failure by the government to provide basic medical services in the two hospitals, leading to the avoidable death of the two mothers, was a violation of their right to life (article 22); respect for human dignity and protection from inhuman treatment (article 24); women's rights (article 33); amendment $8 \mathrm{~A}$; as well as the various health provisions set out in the National Objectives and Directive Principles of State Policy. The court also sought to establish whether the case fell under article 45 which prescribes that ' $[\mathrm{t}] \mathrm{he}$ rights, duties, declarations and guarantees related to fundamental and other human rights and freedoms specifically mentioned in this chapter shall not be regarded as excluding others not specifically mentioned'.

While raising preliminary objections, the state maintained that the case could not be decided by the court as it asked 'political questions' that were in the jurisdiction of the legislature and the executive. Thus, by adjudicating the case, the court would be concerning itself with issues that were not in their jurisdiction and, thus, would infringe on the principle of separation of powers. The court agreed with the state and dismissed the case.

As a result of the dismissal of the CEHURD case by the Constitutional Court, it was appealed to the Supreme Court. ${ }^{50}$ The Supreme Court reiterated the role of the Constitutional Court as per article 137. On the issue that the petition did not raise issues calling for constitutional interpretation, the Supreme Court pointed out that according to their pleadings, the appellants had clearly specified the acts and omissions by the government and the health workers which they maintained were inconsistent with the Constitution. The particular provisions of the Constitution that the government and its health workers were alleged to have violated were also spelt out. The appellants further asked for specific declarations as well as redress. The Supreme Court ruled that the matters raised competent questions for the Court to hear and interpret, to ascertain whether the petitioners' allegations warranted the Constitutional Court to issue the declarations or grant the redress sought for by the petitioners as per article 137 of the Constitution. On this ground, the Supreme Court noted that the Constitutional Court had erred in its decision. ${ }^{51}$

The other issue, which was the main bone of contention, was that of the 'political question'. The judge referred to article 137(1) of the Constitution. For emphasis, she cited Paul Semwogerere \& Others $v$ Attorney-General, ${ }^{52}$ where it was decided that article 137(1) empowers the courts with unreserved jurisdiction to entertain any

49 CEHURD \& Others $v$ Attorney-General (n 48 above).

50 Centre for Human Rights and Development (CEHURD) \& Others $v$ Attorney-General UGSC Constitutional Appeal 1 of 2013, decided 30 October 2015.

51 As above.

52 Paul K Semogerere \& Others v Attorney-General (Constitutional Appeal 1 of 2002) (2004) UGSC 10 (28 January 2004). 
question pertaining to the interpretation of any constitutional provision. Thus, with regard to interpretation, the Court's powers are unlimited and unencumbered. She further added that article $137(3)(b)$ stated that any person who claims that any act or omission by any person or authority contravenes a provision of the Constitution may petition the Constitutional Court for redress or a declaration to that effect where applicable. Therefore, based on these grounds, the Supreme Court unanimously ruled on 30 October 2015 that the Constitutional Court hear the petition based on its merits. ${ }^{53}$

The inclusion of other violated rights in the case is based on the principle of the interrelated nature of rights which presupposes that rights are interdependent and, therefore, the violation of one right often inevitably triggers the violation of several others. This approach is even more vital in cases where the main right in question is not provided for in the Bill of Rights. The right to health is not provided for in Chapter 4 (fundamental and other human rights and freedoms) but rather is reserved for the section on National Objectives and Directive Principles of State Policy. In its first Concluding Observation to Uganda, the ESCR Committee clearly pointed out the need for the inclusion of the right to health in Uganda's Bill of Rights as well as in other laws where necessary. ${ }^{54}$ The Technical Guidance on Maternal Mortality and Morbidity also emphasised that among the steps that need to be taken in order to empower women to claim their rights is the express recognition of the right to health, including sexual and reproductive health, in constitutions and other legislations. This should be accompanied by the putting in place of effective accountability mechanisms in case these rights have been violated. ${ }^{55}$ Similarly, the recently-adopted General Comment 22 on Sexual and Reproductive Health Rights calls upon states to enshrine the right to sexual and reproductive health in the justiciable parts of the Constitution at the national level, pointing out to lawyers, judges and prosecutors that this right can be enforced. 56

Another issue that courts tend to side-line is the position of article $8 \mathrm{~A}$ of the Constitution. In order to elevate the status of the Directive Principles, an amendment to the Constitution in terms of article 8(A)(1) was added in 2005. The amendment points out that 'Uganda shall be governed based on principles of national interest and common good enshrined in the National Objectives and Principles of State Policy'. ${ }^{57}$ Margaret Zziwa justified the inclusion of this clause by

As above.

ESCR Committee Concluding Observations to Uganda (n 14 above). United Nations General Assembly (n 42 above) para 12.

ESCR Committee General Comment 22 on the Right to Sexual and Reproductive Health (art 12 of the ICESCR) E/C 12/GC/22, 2 May 2016, para 64.

57 The Constitution (Amendment) Act 2005 insertion of art 8A. 
stating: 58

In order to strengthen the culture and spirit of nationalism, it is important to have the minimum interests or the minimum elements ... to be the guiding principles of state policy. And these interests must be stated in the justifiable part of the Constitution in order to give them a permanent feature, which must be implemented by all government agencies.

The issue of National Objectives and Directive Principles of State Policy is not restricted to Uganda. Elsewhere courts have used the principle of the interdependent nature of rights to argue cases usually reserved for this section. Okeke argues that in an ideal situation, all the constitutional provisions should be justiciable as well as enforceable. $^{59}$ In the case of Olga Tellis, ${ }^{60}$ concerning the forceful eviction as well as the demolition of the structures of slum dwellers, the Indian Supreme Court maintained that the right to life was inclusive of the right to livelihood because no person can live without the basic means of living. Thus, the Court turned the right to livelihood, which appears in the Directive Principles of State Policy, into an enforceable right. Even though the Court declined to provide the remedies requested by the applicants, this is an example of using constitutionally-recognised civil and political rights in advocating social rights. Similarly, in the Nayadu case, ${ }^{61}$ the Court broadly interpreted article 21 (the right to life) of the Indian Constitution as encompassing the right to water. The Court emphasised that it was incumbent upon the state under article 21 of the Indian Constitution to ensure access to clean drinking water for the Indian population. Ghana took a much bolder step by directly declaring that the Directive Principles of State Policy were justiciable in the case of Ghana Lotto Operators Association, which had been decided by the Supreme Court in 2008. ${ }^{62}$ The Court held that the economic, social and cultural rights spelt out in Chapter six of the Ghanaian Constitution, which provides for the Directive Principles of State Policy, are themselves assumed to be justiciable. ${ }^{63}$

The CEHURD \& Others $v$ Attorney-General case sought to resolve issues such as the position of article 8A (on National Objectives and Directive Principles of State Policy). By dismissing the case, the opportunity to elaborate on such issues was lost. It remains to be seen how the Constitutional Court will resolve the case. It is hoped that it

58 Parliament of the Republic of Uganda (2005) Hansard Report 15 August 2005, http://www.parliament.go.ug/new/index.php/documents-and-reports/dailyhansard (accessed 20 October 2013).

59 GN Okeke \& C Okeke 'The justiciability of the non-justiciable constitutional policy of governance of Nigeria' (2013) 7 IOSR Journal of Humanities and Social Sciences 11.

60 Olga Tellis \& Others $v$ Bombay Municipal Corporation \& Others ETC 10 July 1985 SCR 51 2.1-2.2.

61 AP Pollution Control Board v Prof MV Nayudu 2000 SCALE 354 para 3.

62 Ghana Lotto Operators Association \& Others v National Lottery Authority (2009) 3 SCGLR 235.

63 As above. 
will take a broad rather than a restricted understanding of the position of maternal health rights in the Constitution and other related legislation.

Another important case was brought before the High Court by CEHURD (CEHURD \& Others $v$ Nakaseke District Local Government). ${ }^{64}$ In this case, Mugerwa David together with CEHURD accused Nakaseke District Local Government of negligence which had led to the death, caused by obstructed labour, of his wife, Nanteza Irene, leaving behind three dependants. It was alleged that Nanteza had come to the hospital in the advanced stages of labour and after observation she was found to be undergoing obstructed labour. However, the doctor on duty was not at the hospital and only returned after more than four hours from the time when the mother was diagnosed. As a result, eight hours after she had arrived at the hospital, Nanteza passed away before surgery could be performed. The judge ruled that the failure to promptly attend to Nanteza, as a result of the absence of the doctor on duty, was a violation of her right to basic medical care. The hospital was ordered to pay damages to her family in the amount of 35 million shillings.

The Nakaseke judgment was a mixture of a cause of action based on negligence and an action based on the violation of constitutionally-guaranteed rights provided for under article 50 of the Constitution dealing with the enforcement of rights. ${ }^{65}$ Therefore, the Court could have ruled on the matter by solely relying on the cause of action in negligence. Indeed, the Court found that the doctor had caused the death of the deceased by neglecting his duty to care for her. However, the judge also ruled that the failure to promptly provide medical care to the deceased was a violation of her maternal health rights as well as her right to basic medical care.

Article 50 is another important provision as far as ensuring access to justice as well as strategic litigation are concerned. Article 50(1) provides that '[a]ny person who claims that a fundamental or other right or freedom guaranteed under this Constitution has been infringed or threatened, is entitled to apply to a competent court for redress which may include compensation'. It also gives the courts the power to provide redress, including compensations, declarations and damages. ${ }^{66}$ Article 50(2) empowers both individuals and organisations to bring an action on the ground of the violation of another person's human rights. Indeed, the maternal health cases

64 Centre for Health, Human Rights and Development \& Others v Nakaseke District Local Government UHC Civil Suit 111 of 2012, decided 30 April 2015.

65 'Ugandan High Court finds human rights violations where a pregnant woman died of a ruptured uterus and blood loss while in labour' Legal Grounds III, Case 20, http://www.law.utoronto.ca/utfl_file/count/documents/reprohealth/lg-20_ cehurd_nakaseke_uganda.pdf (accessed 10 December 2017).

66 CEHURD 'Litigating maternal health rights in Uganda: What civil society groups must know' September 201315. 
mentioned above were brought by a civil society organization (CEHURD) on behalf of vulnerable individuals.

Article 50(4) states that Parliament shall make laws for the enforcement of rights and freedoms in this chapter. The fact that Parliament has not yet enacted a comprehensive law on the enforcement of rights has posed a challenge. In the Bukenya case ${ }^{67}$ the petitioners were appealing the Constitutional Court decision which had declared the Fundamental Rights and Freedoms (Enforcement Procedures) 2008 unconstitutional on the basis that they had been produced by the Rules Committee rather than Parliament, thus contravening article 50(4) of the Constitution. The Supreme Court ruled that the Procedures were constitutional and that the Rules Committee had acted within its powers in providing for a procedure to seek redress for violations of fundamental rights and freedoms under article 50(1). The Court also stressed that by invalidating the Procedures, the Constitutional Court had created a scenario where anyone who wanted to seek redress under article 50(1) for human rights violations had no recourse to courts until Parliament enacted a law under article 50(4). At the same time, the Court was exasperated by the fact that 22 years after the enactment of the Constitution, Parliament had not yet enacted a comprehensive law for the enforcement of rights.

Another issue of contention is the procedure to be followed in bringing cases under article 50 of the Constitution. Normally the procedure for bringing cases to the High Court is by plaint. This procedure is quite lengthy as it has to be supported by a summary of evidence; a list of authorities to be relied on; a list of witnesses; and any documents relating to the violation should be availed to support the claim. ${ }^{68}$ However, in the Charles Harry Twagira case, ${ }^{69}$ the Supreme Court overturned the Constitutional Court ruling which had held that an action could only go to the High Court under article 50 of the Constitution on a plaint. The judge stated:

In my considered opinion, a person who claims that a fundamental or other right or freedom guaranteed under the Constitution has been infringed can institute an action in a competent court by plaint or can seek declarations by notice of motion depending on the facts of complaint within the meaning of article 50.

Nonetheless, all these contentions and positions can be confusing to those wishing to bring human rights cases before courts. This calls for the speedy enactment of a comprehensive law on the enforcement of fundamental rights and freedoms by Parliament as required by article 50(4) of the Constitution and as emphasised in the Bukenya case. In

67 Bukenya $v$ Attorney-General UGSC Constitutional Appeal 3 of 2011 [2017] 18 (22 May 2017).

68 As above.

69 Charles Harry Twagira v Uganda UGSC Criminal Appeal 27 of 2003 [2005] 14 (3 August 2005). 
the meantime, courts should ensure that the position taken serves the purpose of expanding rather than limiting access to courts of people whose rights have been violated.

Ultimately, the adjudication of cases pertaining to maternal death and morbidity is an uphill task, especially in the context of Uganda where the justiciability of the right to health remains in question. As highlighted by Ngwena, in the absence of a succinct constitutional mandate, courts are in murky waters when it comes to the adjudication of the right to health. Even where there is a constitutional mandate, courts may be restrained in order not to seem to be entering into the realm of the executive. ${ }^{70}$ The prioritisation of economic, social and cultural rights also starts from the curriculum for legal practitioners. As noted by Onyango, the challenge with the enforcement of economic, social and cultural rights starts with law schools where the field hardly features in regular curricula. This creates a challenge of lawyers who lack the required skills to successfully litigate economic, social and cultural rights cases. ${ }^{71}$

Furthermore, formal judicial structures such as courts of law are often perceived by rural or local communities as removed from their daily-lived experiences. A series of factors, such as high illiteracy, a lack of awareness about court operations, high poverty levels (the inability to afford legal fees) and accessibility to courts, especially in the rural areas, prevent women from accessing the legal structures. ${ }^{72}$ It is estimated that over 85 per cent of lawyers are concentrated in Kampala, leaving about 84 per cent of the population without adequate access to legal representation. The majority have to rely on other forms, such as the Local Council Courts. ${ }^{73}$ The courts at the lower levels (Local Council Courts and Magistrate's Courts), which are often more accessible to the communities, are fraught with numerous challenges including understaffing, underqualified staff, insufficient physical structures and pervasively high levels of corruption. ${ }^{74}$ Ultimately, for judicial accountability to be realised, courts should develop both the constitutional but, more importantly, the institutional capability to adjudicate maternal health issues. ${ }^{75}$

70 C Ngwena 'Scope and limits of judicialisation of the constitutional right to health in South Africa: An appraisal of key cases with particular reference to justiciability' (2013) 14 Journal of Health Law 43-64.

71 J Oloka-Onyango When courts do politics: Public interest law and litigation in East Africa (2017) 180.

72 'Rural women and access to justice' FAO's contribution to a Committee on All Forms of Discrimination against Women (CEDAW) half-day general discussion on access to justice, Geneva, 18 February 2013 5. Action Aid 'Strategies for success access to justice for women' (2011) 8, http://www.actionaid.org/publications/ strategies-success-access-justice-women?width=960\&inline=true (accessed 11 July 2016). Uganda, Draft National Legal Aid Policy, 2012 para 2.

73 Draft National Legal Aid Policy (n 72 above) para 25.

74 'The hierarchy composition and functions of courts in Uganda' http:// lawschoolguide.blogspot.co.za/2011/03/heirachy-composition-and-functionof.html (accessed 5 July 2016).

75 Ngwena (n 70 above) 43-64. 


\subsection{Role of the Uganda Human Rights Commission in promoting legal accountability}

Apart from the courts, the Uganda Human Rights Commission (Commission) is an essential accountability organ with a protective and promotional mandate. ${ }^{76} \mathrm{~A}$ vital contribution by a human rights commission is that it provides for more innovative ways of upholding human rights. ${ }^{77}$ Some consider courts of law as too formal, following strict bureaucratic guidelines, being costly and time-consuming, all of which can become impediments to accessing justice. On the other hand, human rights commissions employ numerous methods such as mediation, the formal court system procedures and awareness raising, and often are more accessible and affordable to a greater part of the population. Some of the remedial measures used, such as mediation, have similarities to the African conflict-resolution approach. ${ }^{78}$

The Guidelines establishing the Commission state that its decisions shall have the same effect as that of the court and shall be enforced in the same manner. ${ }^{79}$ Therefore, article 53 of the Constitution sets out that upon a determination that there has been an infringement of any human right, the Commission may order the release of an imprisoned/detained person; compensation; or any legal redress or remedy. A person who is dissatisfied with the order of the Commission may appeal before the High Court and the Commission may not investigate any matter pending before a court or judicial tribunal.

The Commission has a tribunal which receives, investigates, hears and resolves complaints, a mandate bestowed upon it by article 52(1) of the Constitution. In 2014/2015, it resolved 138 complaints in favour of the complainants and dismissed 68 . In line with the right to health, all 12 complaints received were based on discrimination on the grounds of HIV. The Commission attributed the increase in complaints from the five recorded in the previous year to awareness as a result of improved sensitisation on the right to health. The prioritisation of the right to health through measures such as functionalising a right to health unit has increased awareness of health as a right and not simply a commodity, leading to the gradual increase in health-related complaints to the Commission. In 2016, a complaint was lodged with the Commission against Kiboga Local Government, alleging its failure to avail timely emergency obstetric

76 Art 52 Constitution of the Republic of Uganda, 1995.

77 CP Maina 'Human rights commissions in Africa: Lessons and challenges' in A Bösl \& J Diescho (eds) Human rights in Africa: legal perspectives on their protection and promotion (2009) 351.

78 Uganda Human Rights Commission 17th Annual Report to the Parliament of Uganda (2014) 30-32.

79 J Hatchard 'A new breed of institution: The development of human rights commissions in Commonwealth Africa with particular reference to the Uganda Human Rights Commission' (1999) 32 Comparative and International Law Journal of Southern Africa 41-46. 
care to the complainant's spouse, thereby violating her right to health and life. ${ }^{80}$

Upon receipt of a complaint, the Commission gathers information either from individuals or organisations working at grassroots level in a bid to verify the information, and then proceeds to resolve the issue. In order to effectively reach the general population, the Commission has opened up branches and established toll-free lines in all its regions of operation, which people can use to report any type of complaint. ${ }^{81}$ It thus operates as a channel between the people and the government. The Commission then provides feedback to those who have forwarded complaints either by holding legal proceedings and mediation or contacting the purported violator.

In fulfilling its promotional mandate, the Commission in 2008 established a right to health unit which is charged with sensitising citizens on the right to health, monitoring violations in the health sector and ensuring that those whose rights have been violated have access to adequate remedies. ${ }^{82}$ In 2016 the Commission dedicated its most recent annual report to maternal and reproductive health in contrast to previous reports which focused generally on the right to health. It has also annually increased the number of health facilities that it monitors although the number reduced considerably in 2016 as a result of a reduction in funding for the operations of the Commission. ${ }^{83}$

The Commission has also taken to informing stakeholders on the right to health through workshops and conferences. For instance, towards the end of 2015 it organised a multi-stakeholder meeting aimed at discussing the status of implementation of the Universal Peer Review (UPR) recommendations pertaining to the right to health. ${ }^{84}$ As a result of that and other related fora, in preparation for the upcoming UPR review of Uganda in 2016, the commission prepared a report on the implementation of UPR recommendations as well as the remaining issues or gaps that need to be addressed. In line with maternal health, the Commission pointed out the inadequate funding of the health sector budget which affects the number of skilled birth attendants, especially in the hard-to-reach areas, the unavailability of

80 Uganda Human Rights Commission 19th Annual Report to the Parliament of Uganda (2016) 117.

81 Uganda Human Rights Commission Report (n 80 above) VI 15.

82 C Businge 'Health unit launched' The New Vision 30 September 2008, http:// www.newvision.co.ug/new_vision/news/1180102/health-rights-unit-launched (accessed 11 July 2016).

83 Uganda Human Rights Commission (n 80 above) 116.

84 Uganda Human Rights Commission 'UNHRC holds a multi-stakeholder meeting on the status of implementation of the Universal Periodic Review Recommendations on the Right to Health' 27 November 2015, http://uhrc.ug/ uhrc-holds-national-multi-stakeholder-meeting-status-implementation-universalperiodic-review (accessed 11 July 2016). 
emergency obstetric care services in health facilities and the nonreporting of maternal deaths, especially in private facilities. ${ }^{85}$

However, the Commission is not without challenges, among which are the limited resources availed to it by the government in order to conduct its country-wide operations; insufficient human rights personnel (commissioners) to hear cases; and the very slow or sometimes non-payment of compensation to victims of human rights violations. ${ }^{86}$ These challenges get in the way of the effective fulfilment of its mandate towards reducing preventable maternal mortality and morbidity.

\section{Role of other forms of accountability}

The emphasis of human rights accountability has been on remedying violations through formal justice systems, which forms a vital aspect of horizontal accountability. It is for this reason that rights holders will primarily consider going to courts of law when their rights have been violated. ${ }^{87}$ With the increasing judicialisation of economic, social and cultural rights, such as the right to health, courts have been able to receive cases and provide remedies. However, human rights accountability should not be perceived as a product only to be understood and interpreted by lawyers. This is because law is derived from and interlinked with social, cultural and political developments and, thus, should be interpreted in terms of the interrelationships between law, social sciences, and political and cultural fields. ${ }^{88}$ In applying accountability, various forms of accountability need to complement legal accountability to address maternal mortality and morbidity. Some of the most vital forms are administrative and social accountability.

\subsection{Administrative accountability}

Administrative accountability entails the establishment of standard guidelines and norms within the health facilities and within the Ministry of Health aimed at making subordinates accountable to their superiors, and these should often be monitored by an institution with no conflict of interest. Administrative accountability aims at improving the performance of health systems. While other forms of accountability, such as legal, political and social accountability, are external, administrative accountability allows for the direct interaction with systems to improve their operation. The implementation of this

85 Uganda Human Rights Commission 'NHRI submission for Uganda's second Universal Periodic Review' October 2016, para 15.

86 Maina (n 77 above) 361-362.

87 OHCHR (n 36 above) 39-42.

88 M Darrow \& A Tomas 'Power, capture and conflict: A call for human rights accountability in development co-operation' (2005) 27 Human Rights Quarterly 484-485. 
form of accountability requires the setting up of structures right from the Ministry to the lowest health facility to ensure that the policies in place are being implemented, the allocated funds are put to their most appropriate use and identified shortcomings are remedied.

Regulatory institutions, such as Health Service Commission; the Uganda Medical and Dental Practitioners Council (UMDPC); the Uganda Nurses and Midwives Council (UNMC); the Allied Health Professional Council (AHPC); and the Pharmacy Council of Uganda also have a vital role to play in upholding accountability. From time to time, the Uganda Medical and Dental Practitioners Council has used its quasi-judicial role to investigate and give rulings on allegations of professional misconduct against medical practitioners. ${ }^{89}$ However, these regulatory institutions report challenges of being underfunded and under-facilitated, which limits the effective execution of their accountability role. 90

The functionalisation and improvement of various complaints mechanisms at the health facilities is another way of improving administrative accountability. Government has established complaints mechanisms at various health facilities, such as suggestion boxes, tollfree lines and email addresses, through which complaints should be addressed. However, these are almost non-operational. A survey conducted in Uganda on client satisfaction with services in Uganda's public health facilities in 27 districts revealed that in most districts there is an absence of a co-ordinated or institutional approach of dealing with complaints by health facilities. ${ }^{91}$ It further revealed that only 27 per cent of the respondents had at one time made a complaint using the formal channels for conveying grievances. There are numerous instances where the complaints are not addressed by the health system, which greatly discourages communities from expressing their grievances. ${ }^{92}$

Private actors are also a vital aspect of administrative accountability. Article 20(2) of the Constitution provides that all organs of government, agencies and all persons shall respect, promote and uphold the rights and freedoms enshrined therein. In 2010 it was estimated that private health providers constituted 22,5 per cent of all health care providers in Uganda, most of them located in towns, and the number of private hospitals was considerably on the increase, with 23 recorded in 2012 compared to nine in $2011 .{ }^{93}$ Half of the doctors working in the private sector were also working in government

89 BK Twinomugisha Fundamentals of health law in Uganda (2015) 150-156.

90 Ministry of Health 'Road map for accelerating the reduction of maternal and neonatal mortality and morbidity in Uganda' 2007-2015 11.

91 Uganda National Health Consumer/Users Organisation 'Client satisfactions with services in Uganda's public health facilities: A study by the Medicines Transparency Alliance (MeTA)' Uganda, February 2014 VII.

92 Uganda National Health Consumer/Users Organisation (n 91 above) 7.

93 SWECARE Foundation 'Uganda health and partnership opportunities' August 2013 30-32. 
hospitals, while the majority of nurses worked full-time in the private sector. ${ }^{94}$ Of concern is the fact that households contributed the largest proportion of health expenditure through out-of-pocket expenditure. 95 With the exception of non-profit organisations, the aim of private-profit entities is to make money and not to provide for affordable health care. As a result, the privatisation of health services has increased costs, thus decreasing access to health care. ${ }^{96}$ This is characterised by a reliance on private providers as well as out-ofpocket payments at the point of service. ${ }^{97}$ The complexity of the private sector in Uganda also poses a challenge in its classification with some informal for-profit and small-scale providers who are often unlicensed, untrained, unregulated and uninspected. ${ }^{98}$

The Alyne $v$ Brazil case mentioned above emphasised the government's oversight role with regard to private health practitioners by refuting the state's claim that it could not be held liable for the inadequacy and the poor quality of care at the private health care institution in question. It emphasised that the state was directly responsible for the actions of private institutions and, thus, it had the duty to monitor and regulate these. The state was also reminded of article 2(e) of the CEDAW, which emphasises that it has an obligation to take measures towards ensuring that private actor activities, in line with health policies, are appropriate. Subsequently, the Committee recommended that the state ensures that private health facilities comply with international and national standards on reproductive health care. ${ }^{99}$

\subsection{Social accountability}

Social accountability includes initiatives by citizens, as well as civil society, aimed at holding duty bearers (government officials, service providers and politicians) responsible for providing services that they have committed to avail to the community. ${ }^{100}$ There is the implication that the increased involvement of citizens will foster public actors to be answerable to citizens for action taken or not taken and may be sanctioned in cases of failure to respond to these demands (enforcement). ${ }^{101}$ Joshi and Houtzager state that social accountability

\footnotetext{
94 As above.

95 As above.

96 A Chapman 'The impact of reliance on private sector health services on the rights to health' (2014) 16 Health and Human Rights 122-134.

97 As above.

98 Chapman (n 96 above) 120.

99 Alyne da Silva $v$ Brazil (n 44 above) paras 7(5) \& 8(2).

100 E Peruzzotti \& C Smulovitz (eds) Enforcing the rule of law: Enforcing social accountability in new Latin American democracies (2006) 9-11; NG Jayal 'New directions in theorising social accountability?' (2008) 38 Institute of Development Studies 107.

101 V Boydell \& J Keesbury J 'Improving family planning and reproductive health programmes? A review of the literature' The Evidence Project October 2014 1-2 6.
} 
is an ongoing or sustained engagement of policy makers or state agencies by collective actors for actions taken or not taken, which is influenced by historical as well as current factors. ${ }^{102}$

Citizens as well as civil society may undertake a series of strategies together to ensure that policy makers are responsive to challenges raised, including social mobilisation media and complaints mechanisms at health facilities. ${ }^{103}$ In addition to seeking legal remedies in the CEHURD case, CEHURD utilised massive social mobilisation, including various members of civil society, such as the Coalition to End Maternal Mortality in Uganda, the media, members of the academia, as well as the general public, to seek justice for thousands of vulnerable women who die from preventable causes while attempting to give birth. ${ }^{104}$ Social mobilisation is especially important in the Ugandan context where access to courts faces several challenges, ranging from the non-provision for socio-economic rights as fully justiciable rights; compliance with court judgments; poverty; ignorance (lack of access to information); and high legal fees that prevent marginalised sections of the population from accessing the courts. ${ }^{105}$ Even in countries such as South Africa that have made socio-economic rights fully justiciable, litigation on its own, without social mobilisation, may not bring about the required change. ${ }^{106}$ For example, in the ground-breaking case of Grootboom, ${ }^{107}$ despite success in Court, the applicant died seven years after the handing down of the judgment, without a home but still in a shack in Wallacedene. ${ }^{108}$

One success story of combining litigation with social mobilisation is the South African TAC case, ${ }^{109}$ in which the government was ordered not to restrict the availability of a certain drug to a few research

102 Joshi \& Houtzager (n 39 above) 146150.

103 S Ray et al 'Activism: Working to reduce maternal mortality through civil society and health professional alliances in sub-Saharan Africa' (2012) 20 Reproductive Health Matters 40-49.

104 A Russell 'Real justice could finally be delivered in Uganda by key ruling on maternal health' 2 November 2015 http://www.theguardian.com/globaldevelopment/2015/nov/02/real-justice-could-finally-be-delivered-uganda-keyruling-maternal-health (accessed 28 March 2018).

105 Guttmacher Institute 'Contraception and unintended pregnancy in Uganda' Fact Sheet, https://www.guttmacher.org/fact-sheet/contraception-and-unintendedpregnancy-uganda (accessed 13 February 2018); 'Rural women and access to justice: FAO's contribution to a Committee on All Forms of Discrimination against Women (CEDAW) half-day general discussion on access to justice, Geneva, 18 February 20135.

106 M Heywood 'South Africa's Treatment Action Campaign case: Combining law and social mobilisation to realise the right to health' (2009) 1 Journal of Human Rights Practice 14-36.

107 Government of the Republic of South Africa \& Others $v$ Grootboom \& Others (CCT11/ 00) (2000) ZACC 19; 2001 (1) SA 46; 2000 (11) BCLR 1169 (4 October 2000).

108 M Langford et al (eds) Socio-economic rights in South Africa: Symbols or substance? (2014) 187-188.

109 Minister of Health \& Others $v$ Treatment Action Campaign \& Others (TAC) (CCT8/02) [2002] ZACC 15; 2002 (5) SA 721; 2002 (10) BCLR 1033 (5 July 2002). 
centres, but to ensure that all expectant mothers living with HIV have access to this essential drug. Beyond the case, the TAC campaign mobilised a social movement inclusive of poor and black people living with HIV which attracted massive media coverage, enabling the amplification of the issues to a national as well as international case. ${ }^{110}$ The campaign also worked with researchers in the development of alternative policies and plans that would meet the 'reasonableness' criteria that have been emphasised in South African courts. These factors have been lauded for having contributed to the compliance with the judgment as well as the success of the campaign. Subsequently, poor people became personally and socially empowered and thus were in position to advocate their rights. As a result of litigation, coupled with the social mobilisation strategies mentioned above, South Africa adopted an inclusive anti-retroviral treatment programme that is said to be the fastest-growing programme in the world. ${ }^{111}$ Other methods used under social accountability may include community dialogues; the issuing of press statements; budget tracking; advocacy campaigns; public interest law suits; investigative journalism; and demonstrations or protests. ${ }^{112}$

\section{Conclusion}

Accountability is vital for the improvement of laws and policies towards combating preventable maternal mortality and morbidity. It is emphasised that the confusing and limited nature of abortion rights in the law creates a fearful and uncertain environment for women and girls who find themselves pregnant, as well as the health workers who conduct safe abortions. This increases the number of clandestine and unsafe abortions which lead to lifelong illnesses and, in some cases, mortality. Therefore, Parliament should enact a comprehensive law regulating safe abortions but also to put in place actions/reforms to combat unsafe abortions. It is further proposed that steps should be taken to include the right to health, including reproductive health rights, in the Bill of Rights. Maternal morbidity and mortality violate several rights. Therefore, even in the absence of a clear constitutional provision, it can be litigated on the principle of the interrelated nature of rights using rights that are provided for in the fundamental rights and freedoms section of the Constitution. It is also emphasised that accountability extends beyond legal to social, administrative and other forms of accountability. With the weaknesses outlined in formal judicial systems, social mobilisation, administrative regulatory

110 Heywood (n 106 above) 14-36.

111 Heywood (n 106 above) 14-36 16-19 25-26.

112 Women's Democracy Network-Uganda Chapter 'Best practices for enhancing social accountability in Uganda. Lessons from Uganda' April 2014 6; E Lodenstein et al 'A realist synthesis of the effect of social accountability interventions on health service providers' and policy makers' responsiveness' (2013) 2 Systematic Reviews 1-10. 
mechanisms, and increasing community awareness of reproductive health rights play an important role in the reduction of preventable maternal morbidity and mortality in Uganda. 